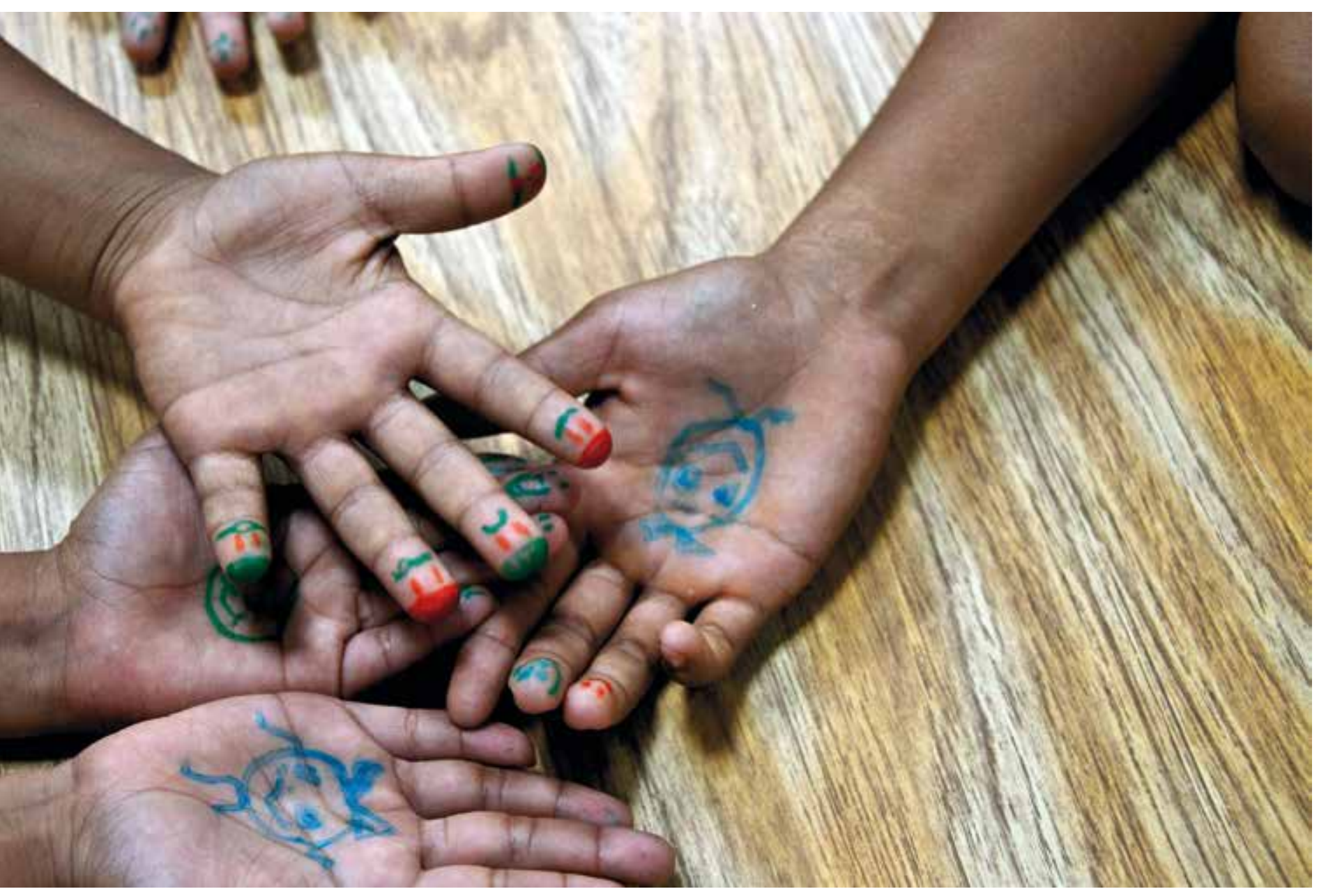

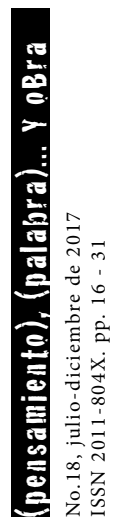




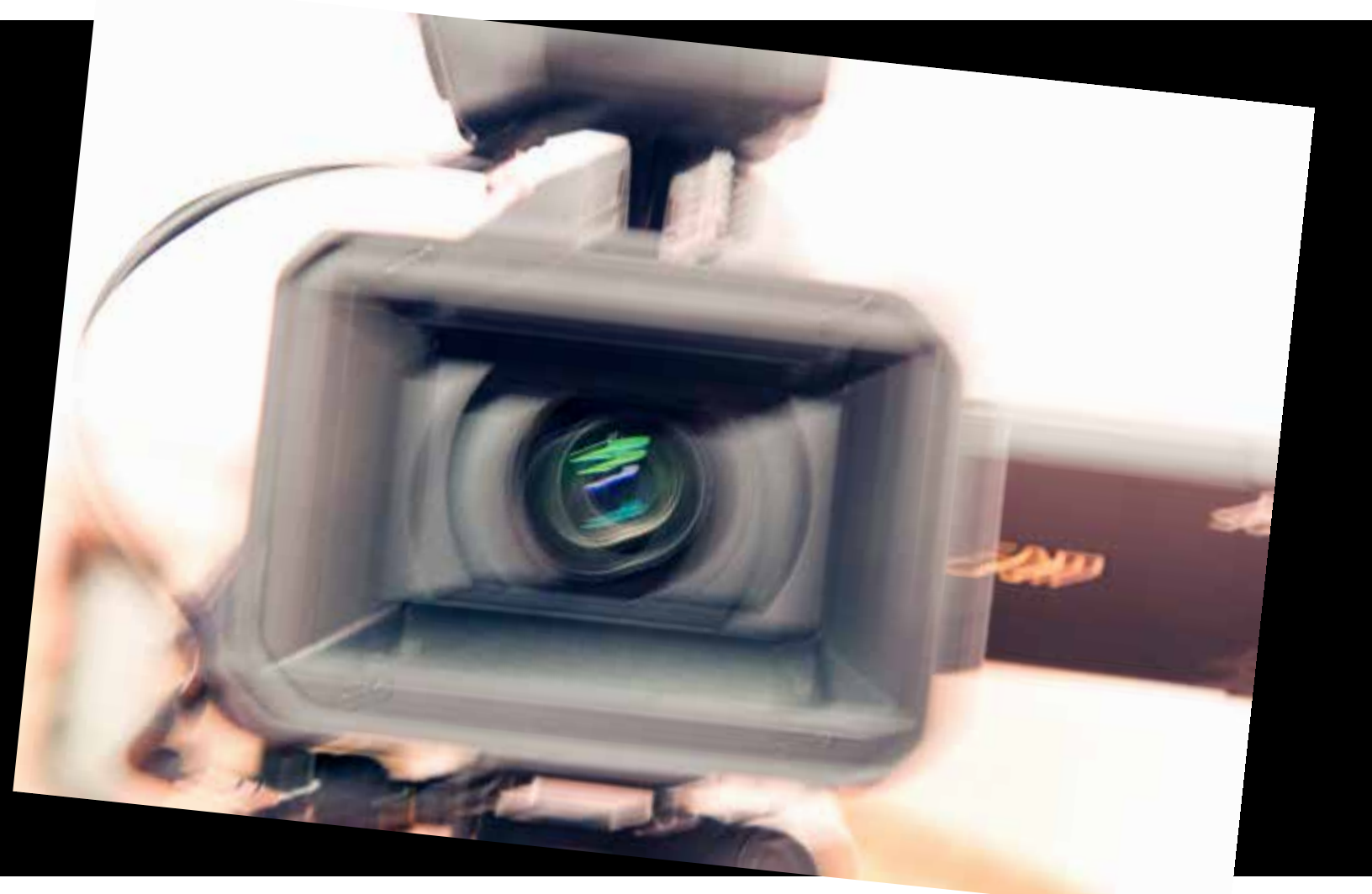




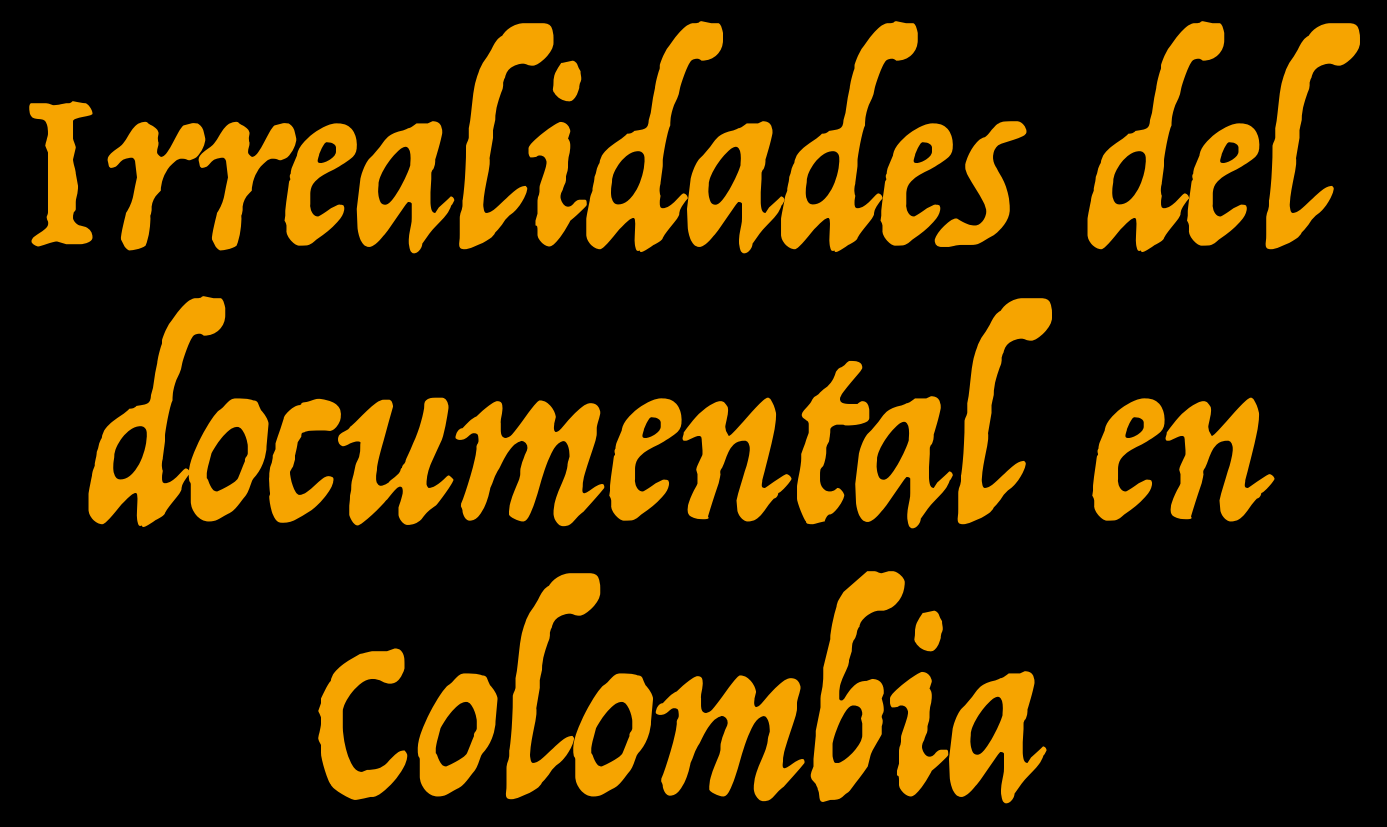

Camilo Eduardo Palacios Obregón 


\section{Irrealidades del documental en Colombia}

\section{Resumen}

La relación entre el género documental y la realidad pareciera ser inevitable, incluso tautológica. El primero debe revelar la segunda, nos han dicho, aunque no por razones semánticas sino ideológicas. Las formas en que este vínculo ha sido desplazado han sido estudiadas por autores como Antonio Weinrichter. El presente escrito articula las tipologías que plantea dicho autor con documentales colombianos de las últimas dos décadas. Se analizan obras que han traspasado las fronteras de su género y que, a partir de su rebeldía contra el paradigma de lo real, han aprendido a develar la apariencia de las falsificaciones, a evidenciar la maleabilidad de las imágenes y a promover el entendimiento de las subjetividades.

Palabras clave: documentales colombianos; realidad en el cine; no ficción; paradigma del documental; Antonio Weinrichter.

\section{Unrealities of the Documentary Genre in Colombia}

\begin{abstract}
The relationship between the documentary genre and reality seems to be inevitable, even tautological. We have been told that the former should reveal the latter, although not for semantic but ideological reasons. The ways in which this link has been displaced have been studied by authors like Antonio Weinrichter. This paper articulates the typologies proposed by this author for Colombian documentaries of the last two decades. We analyze works that have pushed the frontiers of their genre and that, through their defiance of the paradigm of the real, have learned to disclose the appearance of falsifications, to demonstrate the malleability of images, and to promote the understanding of subjectivities.
\end{abstract}

Keywords: Colombian documentaries; reality in cinema; nonfiction; paradigm of the documentary genre; Antonio Weinrichter.

\section{Irrealidades do documental na Colômbia}

\section{Resumo}

A relação entre o gênero documental e a realidade pareceria ser inevitável, até mesmo tautológica. O primeiro deve revelar a segunda, é sabido, ainda que não por razoes semânticas senão ideológicas. As formas nas que este vínculo está se quebrando foram estudadas por autores como Antonio Weinrichter. O presente escrito articula as tipologias que expõe o autor com documentais colombianos das últimas dois décadas. Analisam-se obras que traspassaram as fronteiras de seu gênero e que, a partir de sua rebeldia contra o paradigma do real, aprenderam como revelar a aparência das falsificações, como evidenciar a maleabilidade das imagens e promover o entendimento das subjetividades.

Palavras chave: documentais colombianos; realidade no cine; não ficção; paradigma do documental; Antonio Weinrichter.

\section{Paradigmas y clasificaciones}

El español Antonio Weinrichter, en su libro Desvíos de lo real. El cine de no ficción ${ }^{1}$ (2004), da cuenta de la diversidad contemporánea de películas catalogadas como documentales que se alejan del paradigma del encuentro de lo real. Este paradigma se desarrolla principalmente con el nacimiento en los años sesenta de un movimiento que abogaba por el cine directo, una forma cinematográfica que buscaba plasmar una realidad objetiva en el audiovisual $^{2}$. Para sus defensores, esto se lograba al evitar intervenir en el entorno o en los personajes de manera alguna y al alejarse de lo expresivo, intentando ser esa mosca en la pared que se encuentra en el lugar y tiempo apropiados para descubrir una verdad.

Estas ideas han tenido una enorme repercusión en el concepto aceptado socialmente de lo que debe ser un documental y, al mismo tiempo, han sido blanco de las objeciones de un sinnúmero de autores y cineastas que ven imposible la consecución de dichos objetivos. Para Weinrichter (2004, p. 15),

La concepción misma del
cine documental parte de una
doble presunción ciertamente
problemática, se define en primer
lugar, por oposición al cine de
ficción y en segundo lugar como
una representación de la realidad
[...] toda forma de representación
incurrirá siempre por definición en
estrategias que acercarán la película
del lado de la ficción con lo que se
invalida la primera presunción.

La necesidad de definición de géneros, de catalogación, de reglamentación, ha sido desde siempre una de las grandes problemáticas del arte. Pareciera ser una necesidad inevitable de los teóricos invadir los espacios de creación de los artistas e imponer sus propios puntos de vista. Esto, sumado a las necesidades prácticas del mercado para movilizar los productos, hace que se promuevan generalizaciones que restringen la pluralidad de concepciones que identifican al arte.

Por ejemplo, John Grierson (1998), realizador y teórico del cine señalado de acuñar el término documentary tras ver la película Moana (1926) de Robert Flaherty, en su visión de este género como un arma de intervención social planteaba:

1 Weinrichter prefiere llamar a los documentales no ficciones, ya que cree que el concepto de documental no logra abarcar la gran diversidad del trabajo que se está llevando a cabo en la actualidad.

2 La idea de objetividad en el cine estuvo presente desde sus inicios. El Kino-Pravda (Cine Verdad) de Dziga Vertov, por ejemplo, ya planteaba esta noción en los años veinte. A finales de los años cincuenta y principios de los sesenta, estas búsquedas se potencian con la llegada de equipos más livianos al medio. La película canadiense Les raquetteurs (1958) de Michel Brault y Gilles Groulx, la francesa Chronique d'un été (1961) de Edgar Morin y Jean Rouch, y las estadounidenses Yanqui, No! (1960) y Primary (1960) de Drew Associates son algunos de los primeros ejemplos de estas nuevas exploraciones. 
Creemos que el actor original y la escena original son las mejores guías para una interpretación cinematográfica del mundo moderno [...] Le dan [al cine] el poder de la interpretación sobre hechos más complejos y asombrosos que los que pueda conjurar la mente del estudio, ni recrear la mecánica de ese estudio. (1998, p. 141).

Grierson no solo le da una obligación moral al documental sino que lo pone por encima de su presunto contendor, la ficción. Este mismo autor propuso una de las acepciones de documental más ampliamente referenciadas, al definirlo como la interpretación creativa de la realidad $(1933$, p. 8). Curiosamente esta definición tiene el problema de que también se podría aplicar fácilmente a la ficción.

El mismo Flaherty, quien inspiró gran parte de la teoría griersoniana, muchas veces se apoyó en actores para la consecución de sus objetivos durante los rodajes de sus documentales, y llegó a argumentar que a menudo tenía que distorsionar las cosas para captar su verdadero espíritu (Rabiger, 2003, p. 290). En su artículo Documental y poesía, Rabiger plantea que la contribución de Flaherty al canon del documental fue establecer con sus actores relaciones de colaboración en las que se replanteaban las historias, para dar una dimensión mayor de significado como la que brindaba el cine de ficción. Para este autor, Flaherty es un poeta que comprendió que el cine que no es de ficción "cae inerte en la placidez a menos que el director tome medidas para encontrar significados trascendentes. Esto no es distorsionar ni negar la realidad, sino elevar sus significantes" (Rabiger, 2003, p. 290).

Así como Grierson, ha habido a través de la historia numerosos autores que han promovido su propia concepción del documental como la más apropiada. Desde Dziga Vertov, con su teoría del cine-ojo, pasando por Jean Rouch y el cinema verité, hasta Joris Ivens, precursor del documentalismo social militante. En Colombia, las muestras de esta tendencia también han sido constantes, con una particular propensión a promover el nacionalismo, y la necesidad de crear y exhibir una identidad colombiana en el cine. Carlos Álvarez en el prólogo a su libro Sobre cine colombiano y latinoamericano (1989) planteaba que el cine en un país como el nuestro " $[. .$.$] es un conjunto que debe retroalimentarse en el proyecto de construir$ una cultura auténtica, nacional y que refleje los valores de nuestra sociedad, vertiginosamente cambiantes, y no siempre hacía estadios más elevados” (p. 9).

Esta opción reduce las posibilidades del arte al imponerle compromisos temáticos regionalistas. Al respecto, Francisco Norden proponía que el cine colombiano no tiene en común más que el lugar de juego: "los cines nacionales existen, no en función de sus elementos artísticos, sino en función de sus capacidades de mercadeo" (1978, p. 235). Las reclamaciones a las películas vienen desde múltiples orígenes y pretenden estar presentes desde la concepción misma de la idea. Jean Breschand propone que desde el instante en el que una obra audiovisual inventa su propia forma de existencia no tiene sentido intentar aplicar alguna codificación externa puesto que "no existe el arte puro, porque no son los códigos sino las desviaciones las que crean la obra" (2004, p. 5).

Weinrichter desarrolla su trabajo a partir del análisis de un tipo específico de documentales, en su mayoría producidos en las últimas décadas, que se caracterizan por traspasar las fronteras que los diferentes teóricos han definido sobre lo que debe ser este género. Estas separan el territorio del documental con sus dos vecinos: el cine experimental y el de ficción. Así mismo, describe tres características que se encuentran en los audiovisuales ubicados en estas zonas de concurrencia: una falsedad en las imágenes que imita los patrones documentales; un uso de material de archivo al que se le da un nuevo significado; y una tendencia ensayística que evidencia la subjetividad del autor.

Como veremos a continuación, en el cine colombiano se encuentran cada vez más propuestas que buscan explorar estos territorios y características, lo cual trae consigo resultados que no solo aportan al desarrollo del arte audiovisual nacional sino que también pueden promover actitudes y valores beneficiosos para la sociedad en general. 


\section{Camuflajes socarrones}

En primer lugar, encontramos los falsos documentales, con Un tigre de papel (2008) de Luis Ospina como uno de sus exponentes más importantes en Colombia. Con la excusa de la narración de la vida de Pedro Manrique Figueroa, el supuesto precursor del collage en Colombia, Ospina parodia deliberadamente las convenciones establecidas por el cine documental. Como él mismo plantea en la nota del director incluida en la difusión de prensa de la película, buscaba cuestionar "[...] la validez última de los acontecimientos históricos documentados, proyectando una sospecha sistemática sobre las capacidades técnicas, prácticas e institucionales de la creación de realidades verdaderas y su credulidad" (citado en Cruz, 2008, p. 120).

Para esto, confecciona un acompañamiento a una generación que durante los sesentas y setentas creyó en las ideas que los movimientos de izquierda promulgaban para lograr un avance real hacia la igualdad en el mundo, y que posteriormente se enfrentaría a la decepción y desilusión surgidas de la corrupción totalitarista de sus líderes y de la imposición de un sistema mucho más poderoso. $\mathrm{Al}$ mostrar la muerte de estas utopías a partir de personajes que, aunque se representan a sí mismos, tienen diálogos predefinidos e historias no verídicas, Ospina cuestiona lo que es verdadero y lo que es falso tanto a nivel político e histórico como a nivel artístico y mediático.

Weinrichter argumenta la necesidad de estos cuestionamientos con dos ejemplos de puestas en escena que ayudaron al Gobierno norteamericano a justificar su acción bélica en la guerra del Golfo: primero, la narración de una muchacha que describió la muerte de 312 bebés kuwaitíes a manos de las tropas de Sadam Hussein; y segundo, la imagen de un pájaro impregnado de petróleo, bandera de la misma guerra: "El fake y otras formas de apropiación de los formatos televisivos son una respuesta de los cineastas al secuestro de la realidad acometido por la institución televisiva, para ello utilizan su misma estrategia, la confusión de fronteras" (Weinrichter, 2004, p. 71).

En Colombia, dos grupos mediáticos concentran el $74 \%$ de la audiencia de televisión nacional y sus propietarios son personas con participación activa en la esfera política y pública del país. La enorme influencia que pueden tener estos en la opinión pública es evidente y se hace previsible que sus intereses políticos y económicos influyan en las líneas editoriales de sus medios de televisión (Monitoreo de Medios, 2015). Así, es habitual encontrar en los noticieros colombianos un respaldo a ideologías socioeconómicas particulares y una censura reiterativa a determinados grupos políticos. En una situación como esta, se hace imprescindible promover el entendimiento del audiovisual como una visión sesgada del mundo y de la realidad.

De cualquier manera, no todas las no ficciones muestran su subjetividad de forma tan evidente como el caso de los noticieros colombianos. El punto de vista del autor normalmente suele ser más difícil de distinguir, dado el uso de camuflajes que los medios de comunicación masivos nos han enseñado a percibir como ejemplos de realidad en los audiovisuales. Decisiones como cuándo prender o apagar la cámara, la cercanía al objeto que se graba o los planos que quedan en el montaje final describen la mirada única del realizador y son difícilmente identificables por parte de un espectador desprevenido. Según Rabiger, aunque el autor de documentales puede imaginar o elaborar menos, los resultados en la pantalla son solo una apariencia: "El documental nunca es la verdad misma sino un constructo basado en una determinada impresión de la verdad"

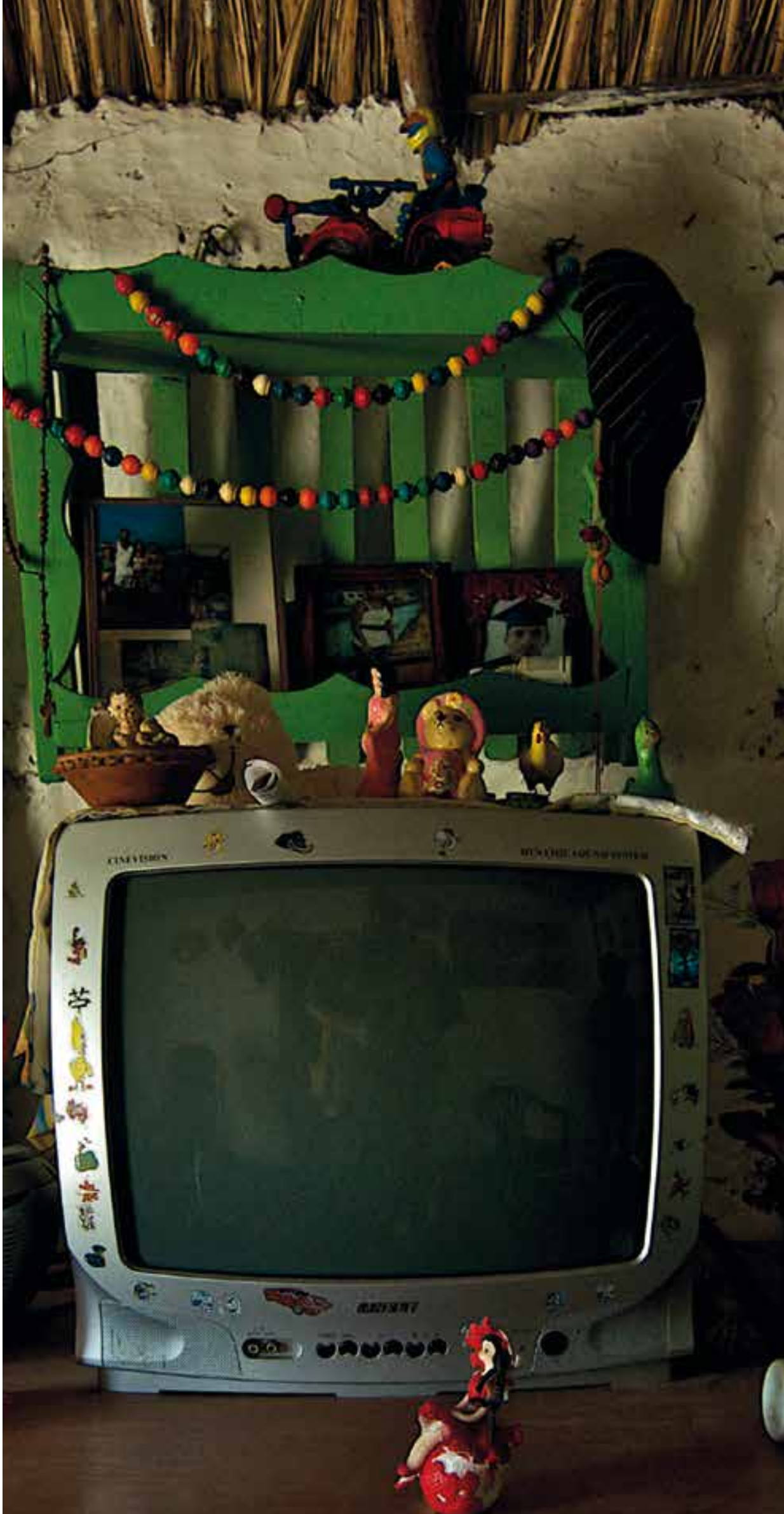


(Rabiger, 2003, p. 288). En un interesante planteamiento, Coutinho y Herrera van más allá al dar un paso atrás y ubicar la realidad no en el producto final sino en su proceso de desarrollo:

Lo único que es real es el encuentro entre el documentalista y el personaje - el acto de rodar - y esa realidad ya me basta. Yo registro ese encuentro. Es un filme. Mi cámara es visible y yo, como documentalista, estoy allí interactuando con las personas. Es un intercambio. Los propios personajes se refieren a ese acto. El documental es un meta-filme. (2003, p. 307).

Así pues, en su búsqueda por afianzar esa sospecha sobre los medios y las instituciones, Ospina logra crear una película en la que no es fácil para todo el mundo vislumbrar la falsedad primigenia del relato. Dado su compromiso con la imitación de las formas, la parodia solo puede ser comprendida por aquellos con ciertas fundamentaciones históricas y artísticas. 30 años antes, este director, junto a Carlos Mayolo, había creado otro clásico: Agarrando pueblo (1977), con objetivos muy afines a los de Un tigre de papel, pero con estrategias bastante diferentes. En este filme, los directores nos permitieron vislumbrar desde el principio la simulación vinculada a su obra. La mezcla de actores profesionales interpretando un guión, actores naturales y personajes reales, además de caricaturizar los referentes estéticos y formales del realismo audiovisual, parodiaba las motivaciones capitalistas ocultas de los autores del llamado cine social y el amarillismo morboso de los espectadores, y develaba así la hipocresía latente tras el supuesto altruismo vinculado a este tipo de documental.

La crítica a este amarillismo será también una de las búsquedas de Memorias del calavero (2014) de Rubén Mendoza, director que ha trabajado con Ospina en varias ocasiones y en quien se puede sentir claramente su influencia. Mendoza nos cuenta la historia de "El cucho", un hombre con un atroz secreto que solo se podrá develar una vez llegue a su tierra natal, en donde, además, su vida y la del equipo técnico del documental correrán peligro. Todo indica que el final logrará satisfacer nuestros más amarillos deseos. Sin embargo, esto no es así, y, por el contrario, lo que encontramos en las últimas secuencias son pistas sobre la presencia de un guión preexistente, un guión del que nunca sabemos qué tanto condujo la trama o en qué momentos lo hizo. Este es un ejemplo de la fácil imitación del realismo que demuestra que esta es una opción estilística atada a una visión de mundo, sesgada como todas, y no una prueba de legitimidad, como pretenden convencernos tanto quienes detentan el poder, como los que no.

\section{Reciclaje y resignificación}

Así como múltiples documentalistas han decidido fabricar sus propias imágenes, otros deciden utilizar materiales previamente grabados con el fin de plantear una idea. El material de archivo usado en los documentales tiene la característica de que fue grabado con intenciones diferentes a las de quien las utiliza. Weinrichter lo plantea como una acción claramente subversiva "por lo que tiene de atentado contra el principio de veracidad del género documental, al desviar el sentido de los materiales reales que utiliza" (2004, p. 80).

Esta subversión la vemos en el trabajo de Camilo Restrepo, un colombiano ganador de premios nacionales e internacionales que reside en Francia desde hace 17 años pero que continúa remitiéndose a su país en cada trabajo que produce. Tropic pocket (2011) es tal vez la película en que más claro se evidencia, casi con carácter de denuncia, el uso del material de archivo con propósitos diferentes a los que originalmente poseían. En ella el autor interviene tres archivos distintos: una docuficción rodada por los padres claretianos en la década de 1950, unos videos de actores del conflicto armado colombiano descargados de Internet y un film publicitario en que se ve un Chevrolet atravesando el Tapón del Darién. A estos, les agrega un material grabado con los habitantes del pueblo de San Pacho, que, aunque fue creado para el filme, logra camuflarse entre los otros. 
La narración generada a partir de estas imágenes explora un mismo trasfondo, la explotación del departamento del Chocó, tema que se potencia a partir de un montaje con gran uso de relocalización y superposición de textos, audios e imágenes. El autor hace evidente este juego de reinterpretación en una clara búsqueda por promover la desconfianza en las imágenes como documento de prueba. En una sociedad fundamentalmente vanidosa, adicta a las promesas de la publicidad y con una conciencia histórica muy poco desarrollada se hace fundamental entender que las imágenes no pueden interpretarse como pruebas de la existencia de ese lugar feliz que estamos buscando ni en el pasado ni en el futuro: ni en el pasado, porque esa supuesta veracidad científica de la Historia está basada en documentos que pueden haber tenido intenciones muy diferentes a las de quien las publica en el presente; ni en el futuro, porque se trata de simulaciones documentales prototípicas del bienestar que los mismos creadores de esas imágenes nos han inculcado. $\mathrm{Al}$ desviarnos de nuestros propios caminos, esa idolatría a las imágenes nos hace vulnerables, nos hace sentir perdidos, estado perfecto para que aceptemos el consejo interesado del primer guía que aparezca.

Sin embargo, existen ejemplos de un uso del archivo en el que las intenciones políticas o de denuncia pasan a un segundo plano, lo que da paso a unas búsquedas más cercanas a lo poético y a la recuperación de la memoria. Se trata de las home movies o cine doméstico, que tienen en el documental 16 memorias (2008) de Camilo Botero uno de sus mejor logrados exponentes en el país. En este se narra la historia de una familia acomodada de Medellín entre 1945 y 1971, a partir de las grabaciones domésticas realizadas por el patriarca de la familia, el ingeniero y fotógrafo empírico Mario Posada. Uno de los grandes logros de Botero es que logra transportarnos a nuestras épocas de infancia a partir del registro de la intimidad de una familia, al mismo tiempo que le da una nueva significación a las imágenes a partir de una dramatización de las situaciones, la cual es lograda de diferentes maneras.

En primer lugar, el montaje concebido a partir de la selección y organización de más de 30 horas de material busca agregar algunos nuevos sentidos al que traen consigo las imágenes. El director montajista aprovecha la vasta cantidad de opciones que tiene para generar nuevas micronarraciones que aportan mucha emotividad al relato. Sin embargo, en ningún momento se ocultan o irrespetan los significados originales del material, por lo que podemos acceder tanto a muestras genuinas de la idiosincrasia y la vida social de los estratos altos de Medellín de esta época, como a una serie de momentos auténticos de la cotidianidad de esta familia. Dichos momentos revelan experiencias únicas, como las conexiones definidas por códigos entre hermanos o las formas del afecto infantil por los padres, situaciones que, así como son mágicas e irremplazables en su propio universo, también se sienten familiares para el espectador, al que irremediablemente conducen a evocar recuerdos y situaciones similares de su propia vida.

En segundo lugar, el director decide usar unos intertítulos al estilo del cine mudo, que representan la voz del hijo mayor de la familia. Estos puntúan, rotulan y separan los contenidos, al mismo tiempo que direccionan nuestras miradas, al hacer énfasis en ciertas acciones y emociones que favorecen las búsquedas del filme. Así mismo, apoyan efectiva y sutilmente esa atmósfera impregnada de nostalgia tan cardinal a través de todo el relato, influenciada también por la textura, el color y la cadencia del material filmado en celuloide por la cámara Bolex de 16 milímetros.

Por último, debido a que el material original era mudo, la sonorización del filme es llevada a cabo completamente en posproducción. Esto no es algo que intente esconderse sino que, por el contrario, su actualidad y, por ende, su carácter artificioso son evidentes en muchos momentos a través del filme, sin que esto afecte la narrativa. Es una banda sonora que logra evocar esa inocencia, espontaneidad y libertad tan definitorias de ese mundo infantil, sin intentar tener un papel principal que pueda eclipsar las imágenes, protagonistas incuestionables de esta película. Son estas las causantes de ese conmovedor sentimiento de añoranza, las cuales logran envolvernos en el aura nostálgica de las recolecciones de ese padre que tanto quería demostrar y atesorar los logros de su dedicación familiar.

En la actualidad, ese acceso sin restricción al registro de los momentos de bienestar y gozo, o al menos de su apariencia, ha pasado de ser un lujo a algo rutinario y maquinal. Como un epílogo al planteamiento de 
Benjamin (1989) sobre la pérdida del aura en las obras de arte a manos de la reproductibilidad técnica, la forma de acercarse a las imágenes del archivo personal ha cambiado progresivamente a través de las diferentes generaciones. La pérdida paulatina de la singularidad de las imágenes ha promovido un abandono del carácter emotivo y nostálgico de nuestro propio registro histórico.

Sin embargo, hay algo en la manera de acercarnos a nuestro archivo que ha sido persistente, y es ese interés en que nuestras representaciones audiovisuales apoyen el imaginario que queremos que los demás tengan sobre nosotros. Con las actuales estructuras sociales virtuales, es cada vez más evidente ese interés en que los otros, los espectadores de nuestras vidas, generen nuevos sentidos de las imágenes domésticas publicadas, nuevos sentidos en los que lo más importante no es la recuperación y transmisión de la memoria sino otras búsquedas, como el apaciguamiento de la vanidad o la validación social. Este tipo de cine nos sirve para entender las imágenes de nuestro propio archivo cotidiano, más que como un indicador de lo que está sucediendo en la realidad, como una metáfora de nuestras propias búsquedas humanas.

\section{Ensayando frente al espejo}

La última característica que analiza Weinrichter se refiere a la tendencia ensayística de muchas películas de no ficción en la actualidad. Son películas en las que ya no se pretende disimular la subjetividad de las voces narradoras, como dicta el paradigma del encuentro de lo real, sino en las que, por el contrario, el planteamiento y desarrollo argumentativo de ese punto de vista es su misma finalidad. Es un cine libre de prescripciones que debe inventarse su propia forma en cada caso y que ha sido beneficiado por la tecnología, ya que esta promueve la independencia para grabar de los individuos, lo que fomenta la narración en primera persona.

Muchos ejemplos en Colombia atestiguan las múltiples posibilidades de esta tendencia. Looking for (2012) de Andrea Said cuenta la historia de la búsqueda en Londres del padre pakistaní de la directora, quien está armada solo con su cámara y algunos pocos datos. La directora narra la historia por medio de una primera persona llena de preguntas y dudas, con lo cual fundamenta su relato en la honestidad. Este distintivo genera una enorme identificación entre los espectadores del filme, lo cual, sumado a la utilización de la fórmula clásica de presentar un objetivo potente y un conflicto para obtenerlo, logra atrapar al espectador desde el comienzo.

Por su parte, Frente al espejo (2009) y En la ventana (2011), de Ana María Salas, no cuentan con estrategias dramatúrgicas clásicas que promuevan el interés en la resolución de un problema. Son dos autorretratos de una joven cineasta y artista colombiana residente en Francia, quien a través de grabaciones de su cotidianidad nos presenta una mirada particular e íntima de lo que circunda su vida; ya sea su rostro, su cuerpo o los objetos que la rodean, las imágenes se sienten naturales e instintivas, guiadas por una necesidad emocional, sensorial o estética de un momento específico, más que por una intención narrativa o intelectual premeditada. Es esta autoexploración genuina, impregnada de libertad a nivel formal, conceptual y metodológico, la que nos genera interés y nos vincula personalmente a la obra. Estas dos realizadoras tienen visiones de mundo con propuestas que se alojan en estrategias narrativas diferentes pero que se encuentran en su despliegue de sinceridad, la cual, al no intentar imponer nada, logra conseguir nuestra empatía.

Otra característica del cine de ensayo es la potenciación de la palabra a partir de la utilización de una voz definida por un guión. Aunque casi siempre es una voz en off, esto no está planteado como una regla, como no lo está nada en este tipo de cine. En El proyecto del Diablo (1999), el realizador caleño Oscar Campo propone como narración principal un monólogo coescrito entre él y el protagonista, un sobreviviente de la calle llamado Fernando "La larva" Córdoba, a quien podemos ver en algunos fragmentos mientras declama el texto. Este evoca la violenta historia de su entorno desde un presente enmarcado por los límites difusos generados por las cicatrices de su existencia, a partir de un relato que, más que demostrar o argumentar, pretende expresar una visión personal y poética. Por más cruda y agresiva que sea la narración, la película nos invita a conocer y entender las razones que generaron las visiones expresadas:

Vengo de mala sangre, de gente del campo, oscura, encorvada sobre la tierra, ajenos a cualquier arte que no sea la bala y el machete. De mi padre dicen que mató a algunos en la época de Laureano. Será por eso que tengo la sangre caliente.

Textos como este muestran el interés del realizador en que el vínculo con el protagonista no sea generado desde la usual perspectiva afectiva y emotiva a la que estamos acostumbrados. Se nos está proponiendo un vínculo más profundo y analítico, derivado de nuestra fascinación por su oscura relación con la anarquía, que si bien lo acerca a los lugares más siniestros de la sociedad y a la muerte misma, lo condena también a una libertad sumergida en sus propias quimeras. El fomento del respeto por las diferencias de opinión que nos propone esta película, al entender que cada persona tiene una realidad propia generadora de pensamientos, es uno de los elementos más importantes de este tipo de cine, en especial para una sociedad dominada por los rencores y el desentendimiento.

Podríamos afirmar, para terminar, que el desafío a las clasificaciones y definiciones teóricas en la no-ficción le brinda a la sociedad y a la comunidad artística nuevos caminos conceptuales, narrativos y formales para el análisis y mejoramiento social. Ya sea al develar la apariencia de las falsificaciones, al evidenciar la maleabilidad de las imágenes o al promover el entendimiento de las subjetividades, la tendencia del cine de no ficción a alejarse del paradigma del encuentro de la realidad tiene la capacidad de abrir las miradas del espectador hacia nuevas perspectivas; perspectivas diferentes a las promovidas por la institucionalidad que apoyan la formación de criterios fundamentados; perspectivas respetuosas de los diferentes puntos de vista que nos orienten cada vez más hacia una sociedad en paz. 


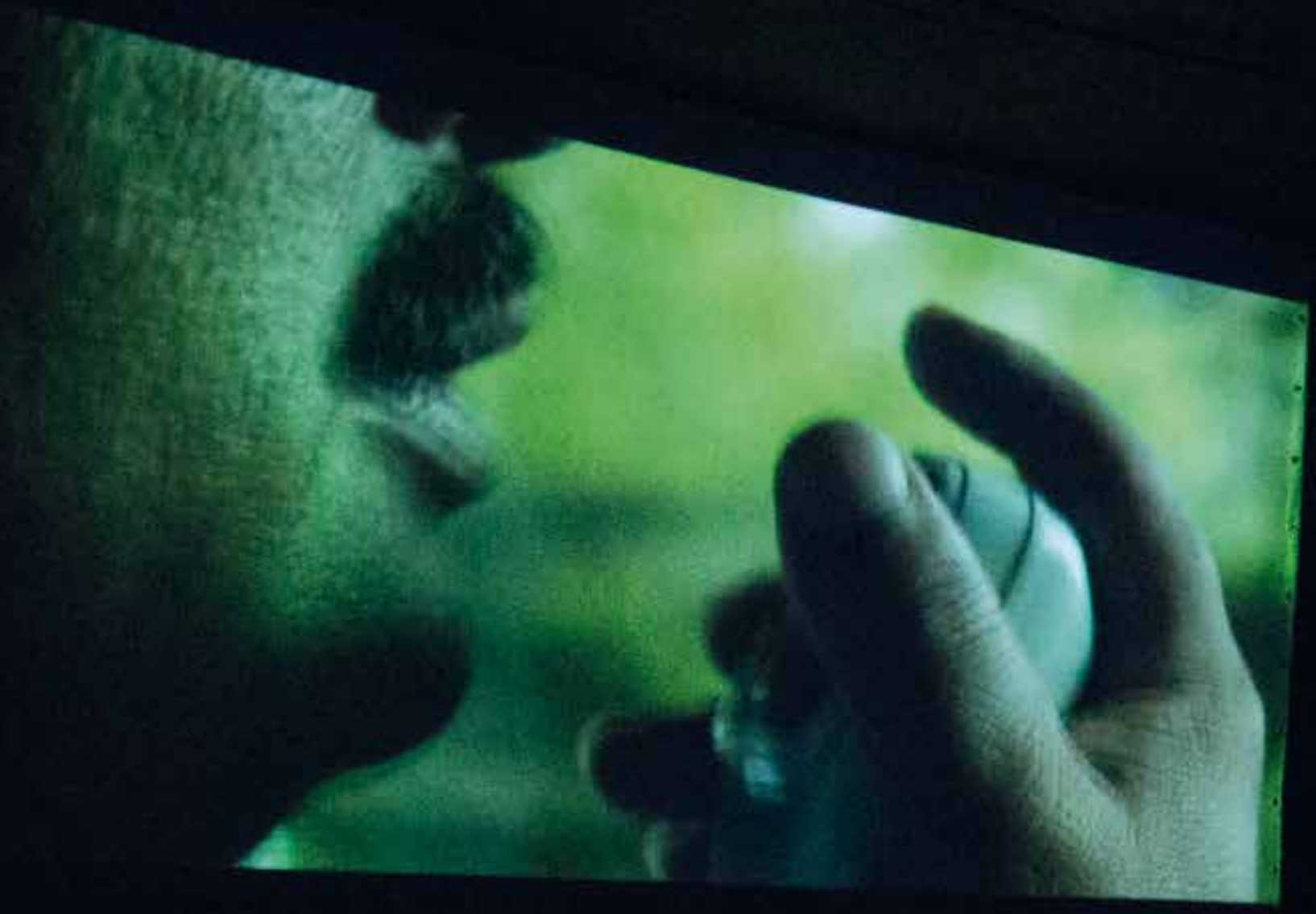




\section{Referencias}

Álvarez, G. (1989). Sobre cine colombiano y latinoamericano. Bogotá: Universidad Nacional de Colombia.

Benjamin, W. (1989). La obra de arte en la época de su reproductibilidad técnica. En Discursos interrumpidos $I$. Buenos Aires: Taurus. 14-60.

Breschand, J. (2004). El documental. La otra cara del cine. Barcelona: Ediciones Paidós Ibérica.

Coutinho, E. y Herrera, J. (2003). El documental como conocimiento poético. Revista Litoral, 236, 306-307.

Cruz, I. (2008). Un tigre de papel especialmente verdadero. Revista Cinémas d'Amérique Latine, 16, 119-123.

Grierson, J. (1933). The documentary producer. Cinema Quarterly, 1(2), 7-9.

Grierson, J. (1998). Postulados del documental. En Textos y manifiestos del cine. Madrid: Ediciones Cátedra. 139-147.

Monitoreo de Medios (2015) Indicadores MOM. Recuperado de www.monitoreodemedios.co/ indicadores -mom/

Rabiger, M. (2003). El documental y la poesía. (Miguel Ángel

Fernández, trad.). Revista litoral, 236, 283-292.

Valverde, U. (1978). Entrevista con F. Norden. En Reportaje crítico al cine colombiano. Bogotá, Cali: Editorial Toronuevo Limitada.

Weinrichter, A. (2004) Desvíos de lo real. El cine de no-ficción. Madrid: T\&B Editores.

\section{Filmografía}

Botero, G. (Director) (2008). 16 memorias [Documental]. Producción independiente.

Brault, M. y Groulx, G. (Directores) (1958). Les raquetteurs

[Documental]. National Film Board of Canada.

Campo, O. (Director) (1999). El proyecto del Diablo [Documental]. Universidad del Valle TV.

Drew, R. (Director) (1960). Yanqui, No! [Documental]. Drew Associates.

Drew, R. (Director) (1960). Primary [Documental]. Drew Associates.

Mendoza, R. (Director) (2014). Memorias del calavero [Documental]. Dia Fragma Fábrica de películas.

Morin, E. y Rouch, J. (Directores) (1961). Chronique d'un été

[Documental]. Argos Films.

Ospina, L. (Director) (2008). Un tigre de papel [Documental]. Producción independiente.

Ospina, L. y Mayolo, C. (Directores) (1977). Agarrando pueblo [Documental]. SATUPLE.

Restrepo, C. (Director) (2011). Tropic pocket [Documental]. Camilo Restrepo Films.

Said, A. (Director) (2012). Looking for [Documental]. Producción independiente.

Salas, A. M. (Director) (2009). Frente al espejo [Documental]. Producción independiente.

Salas, A. M. (Director) (2011). En la ventana [Documental]. Producción independiente.

\section{Camilo Eduardo Palacios Obregón}

Realizador de Cine y Televisión de la Universidad Nacional de Colombia con maestrías en Teoría y Práctica del Documental Creativo de la Universidad Autónoma de Barcelona y en Creatividad y Guiones de Televisión de la Universidad Rey Juan Carlos de Madrid. Amplia experiencia audiovisual como montajista, guionista y realizador. Actualmente es investigador docente en la Universidad Manuela Beltrán, enfocándose en la investigación-creación audiovisual.

camiloepalacios@yahoo.com 